\title{
In Vitro Antioxidant and Enzyme Inhibition Activity of Tanacetum argyrophyllum (K. Koch) Tzvelev var. argyrophyllum Extract
}

\author{
(D) Nuraniye ERUYGUR ${ }^{1 *}$, (D) Kevser TABAN AKÇA², (D) Osman ÜSTÜN2² (D) Mehmet TEKIN³ \\ 1Selçuk University, Faculty of Pharmacy, Department of Pharmacognosy, Konya, Türkiye \\ 2 Gazi University, Faculty of Pharmacy, Department of Pharmacognosy, Ankara, Türkiye \\ ${ }^{3}$ Trakya University, Faculty of Pharmacy, Department of Pharmaceutical Botany, Edirne, Türkiye
}

\begin{abstract}
Objectives: Tanacetum L. belongs to Asteraceae family and is represented by 46 species in Türkiye. Tanacetum genus is known for its insecticide and insect repellent effect. T. argyrophyllum contains sesquiterpene lactone derivatives. These compounds are responsible for its various activities, especially cytotoxic, antitumor, phytotoxic, antimicrobial, antiviral, and antifungal activity. There are not enough biological activity studies on the plant that are likely to have a wide variety of activities in terms of the compounds it contains. The aim of the present study is to evaluate various biological activities of $80 \%$ aqueous methanol extract prepared from aerial parts of T. argyrophyllum (K. Koch) Tzvelev var. argyrophyllum collected from Sivas province of Turkey.

Materials and Methods: Antioxidant activity of the methanol extract was determined by 2,2'-diphenyl-1-picryl-hydrazyl and 2,2-azinobis (3-ethyl benzothiazoline-6-sulfonic acid) radical scavenging activity, total phenolic, and total flavonoid content tests. Acetylcholinesterase (AChE) and butyrylcholinesterase (BChE) inhibitory activities were investigated via Ellman's spectrometric method.

Results: Total phenolic content was found as $71.67 \mathrm{mg} / \mathrm{gallic}$ acid equivalent $\mathrm{g}$ and total flavonoid content was $25.225 \mathrm{mg} / \mathrm{quercetin}$ equivalent g on a dry extract weight basis. In this work, AChE, BChE, and $\alpha$-glycosidase enzymes were inhibited by the extract of T. argyrophyllum var. argyrophyllum. $\mathrm{IC}_{50}$ values for these enzymes were found as $266.79 \mu \mathrm{g} / \mathrm{mL}$ for AChE and $176.91 \mu \mathrm{g} / \mathrm{mL}$ for BChE. Also, the $\alpha$-glycosidase activity exhibited a dosedependent manner with increasing concentration.
\end{abstract}

Conclusion: According to the results, T. argyrophyllum var. argyrophyllum can be used as an ingredient of functional foods as well as herbal products for diabetic and Alzheimer's disease patients.

Key words: Tanacetum argyrophyllum var. argyrophyllum, antioxidant, acetylcholinesterase, butyrylcholinesterase, antidiabetic

\section{INTRODUCTION}

Asteraceae family has approximately 1535 genera around the world, while 138 genera and 1186 species in Türkiye.' The genus Tanacetum $L$. is one of the largest genera in this family and is represented by 46 species, 18 subspecies, and 5 varieties, where its 26 taxa are endemic to Türkiye. ${ }^{2}$ Several members of Tanacetum include medicinally important taxa. According to recent literature, essential oils and extracts of Tanacetum species have antiinflammatory, antibacterial, antifungal, anti-
Alzheimer, and insecticidal effects. ${ }^{3}$ Various biological activities are thought to associate with sesquiterpene lactone content of Tanacetum species. ${ }^{4}$ The interest in the Tanacetum species is increasing day by day due to the fact that it is effective against many diseases due to it is powerful secondary metabolites such as essential oil, sesquiterpenes, sesquiterpene lactones, flavonoids, coumarins, tannins, and sterols. ${ }^{5,6}$ However, there are not enough studies on the biological activity of Tanacetum argyrophyllum (K. Koch) Tzvelev var. argyrophyllum except for their antimicrobial activity.

This study was presented as an oral lecture at the International Symposium on Medicinal, Aromatic and Dye Plants, Malatya, Turkey, 2017. 
Alzheimer's disease (AD) is a neurological disorder characterized by decreased cognitive functions, daily activities, behavioral changes, and psychiatric symptoms. ${ }^{8}$ Acetylcholine is a neurotransmitter released from the synapse of neurons and the biochemical changes in $A D$ are closely related to the reduction of acetylcholine levels in the brain neurons. ${ }^{9}$ Acetylcholinesterase (AChE) has become impressive in drug design studies. Cholinesterase inhibitors are commonly used in $A D$ therapy; however, they can have serious side effects such as gastrointestinal disturbances, fatigue or depression. ${ }^{10}$ The drawbacks of these licensed drugs have pushed researchers to find new and potential inhibitors of $A C h E$ and butyrylcholinesterase (BChE) from plants that have therapeutic properties.

Diabetes mellitus is a metabolic disease marked by an excessive increase in blood glucose levels, which is regulated by $\alpha$-glucosidase and $\alpha$-amylase enzymes. $\alpha$-Amylase initiates carbohydrate digestion by hydrolyzing polysaccharide 1,4-glycosidic linkages to disaccharides. $\alpha$-Glucosidase converts disaccharides into monosaccharides, which causes blood glucose levels to increase after meals. ${ }^{11} \alpha$-Glucosidase inhibitors (AGIs) are a new class of antidiabetic medicines that can control blood sugar levels by inhibiting glycosidase competitively and preventing sugar breakdown. However, AGI drugs are not satisfactory because of fewer in their numbers, lower bioavailability, and gastrointestinal problems. ${ }^{12}$ Therefore, there is a need to research out new and safer AGI inhibitor drugs from natural products.

In the literature review, there are not enough biological activity studies on the T. argyrophyllum var. argyrophyllum. Therefore, the aim of this study was to evaluate the antioxidant, antiAChE, anti-BChE, $\alpha$-glucosidase, and $\alpha$-amylase activity of $T$. argyrophyllum var. argyrophyllum methanol extract in vitro. Total phenolic content (TPC) and total flavonoid content (TFC); as well as 2,2-azinobis (3-ethyl benzothiazoline-6-sulfonic acid) diammonium salt (ABTS) and 2,2'-diphenyl-1-picryl-hydrazyl $(\mathrm{DPPH})$ radical scavenging assays, were used to assess the antioxidant capacity. AChE and BChE inhibition methods were used to determine the anti-Alzheimer activity. $\alpha$-Glucosidase and $\alpha$-amylase enzyme inhibition approaches were used to assess the anti-diabetic activity.

\section{MATERIALS AND METHODS}

\section{Chemicals}

DPPH, ABTS, butylated hydroxy anisole (BHA), $\alpha$-glucosidase (from Saccharomyces cerevisiae, type I, lyophilized powder), AChE (from electric eel type-VI-S, EC 3.1.1.7) and BChE (from horse serum, EC 3.1.1.8), 5,5'-dithiobis (2-nitrobenzoic) acid (DTNB), acetylthiocholine iodide (AChl), butyrylthiocholine chloride $(\mathrm{BChC})$, and galantamine were obtained from Sigma Chemicals Co. (St. Louis, MO, USA). All of the other chemicals used were of analytical grade.

\section{Plant material}

The plant material was gathered from a natural habitat during the flowering period. Locality data of collection: Turkey- B6
Sivas: Şerefiye to Suşehri, of Abdiağa Çeşmesi, steep slope, $39^{\circ}$ 59' 41,2" N, 37 43' 45,7" E, 1529 m, June 27, 2016, M. Tekin 1739. The dried specimens were preserved at the Sivas Cumhuriyet University, Faculty of Science Herbarium, Department of Biology, Sivas, Türkiye. Taxonomical identification was done based on the Flora of Türkiye (Davis, 1966) by botanist Dr. Mehmet Tekin, Trakya University (Edirne, Türkiye), Department of Pharmaceutical Botany.

\section{Preparation of the extract}

The plant's aerial parts were dried at room temperature. Then, the dried materials were grounded to powder using a laboratory type mill and macerated with methanol:water: 80:20 ( $/ \mathrm{v})$ for $24 \mathrm{~h}$ at room temperature. The extracts were filtered and the solvent was removed by rotary evaporation at $40^{\circ} \mathrm{C}$. This extraction process was repeated with the residue three times ( $24 h \times 3)$. Extract obtained from the process was held at $+4^{\circ} \mathrm{C}$ until it was used.

\section{Antioxidant activity}

\section{Determination of total phenolic content}

TPC was determined as gallic acid equivalent (GAE) according to the procedure..$^{13}$ In a test tube, $2.5 \mathrm{~mL}$ of $7.5 \%$ sodium carbonate solution and $2.5 \mathrm{~mL}$ of $0.1 \mathrm{~N}$ Folin-Ciocalteu's reagent were combined with $500 \mu \mathrm{L}$ of test solution $(2 \mathrm{mg} / \mathrm{mL}$ ). After vortexing, the tubes were left in the dark for $2 \mathrm{~h}$ and the absorbance was measured using a ultraviolet-visible (UV-vis) spectrophotometer (Shimadzu, UV-VIS 1800, Japan) at $730 \mathrm{~nm}$. The extract's TPC was calculated as mg GAE per gram of dry extract.

\section{Estimation of total flavonoid content}

TFC was measured by a colorimetric method using aluminum chloride according to the procedure of Yang et al..$^{14}$ and the results were given in milligrams of quercetin equivalent (QE) per gram of dry extract. TFC was calculated using an equation derived from the normal concentration-response graph of quercetin.

\section{$D P P H$ radical scavenging activity}

DPPH radical scavenging capacity of the extract and standards (BHA and $\mathrm{BHT}$ ) was evaluated using the previously described method with slight modifications. ${ }^{15}$ Various concentrations of test sample $(100 \mu \mathrm{L})$ were combined with $100 \mu \mathrm{L}$ of methanol containing $\mathrm{DPPH}(0.1 \mathrm{mM})$ and incubated at $25^{\circ} \mathrm{C}$ for 30 min in the dark. The absorbance was read with a UV-vis spectrophotometer at $517 \mathrm{~nm}$. Percentage of inhibition was found according to the formula:

$\%$ inhibition $=\left(A_{0}-A_{t}\right) / A_{0}{ }^{*} 100$,

where $A_{0}$ represents the absorbance of the control without sample and $A_{t}$ represents the absorbance of test solution.

\section{ABTS radical scavenging assay}

The assay of $\mathrm{ABTS}^{\cdot+}$ radical cation decolorization was used to assess radical scavenging activity of the extract according to the method of Re et al. ${ }^{16}$ The stock solution of ABTS ${ }^{\cdot+}$ was generated by mixing $2.45 \mathrm{mmol} / \mathrm{L}$ potassium persulfate with 
$7 \mathrm{mmol} / \mathrm{L}$ ABTS. The mixture stood for in the dark at room temperature for 12-16 h. Diluting the stock with methanol yielded an ABTS ${ }^{*+}$ working solution; the absorbance was $0.70 \pm$ 0.02 at $734 \mathrm{~nm} .100 \mu \mathrm{L}$ sample solution was combined with 100 $\mu \mathrm{L}$ of $\mathrm{ABTS}^{\cdot+}$ working solution and incubated for $7 \mathrm{~min}$ at $25^{\circ} \mathrm{C}$. A UV-vis spectrophotometer set to $734 \mathrm{~nm}$ was used to read the absorbance of the mixture.

\section{Determination of anticholinesterase inhibition activity}

The inhibitory activities of AChE and BChE were determined using Ellman's spectrophotometric method ${ }^{17}$ with minor modifications. In a 96 well-plate, $0.14 \mathrm{~mL}$ of $0.1 \mathrm{mM}$ sodium phosphate buffer ( $\mathrm{pH} 8.0$ ), $0.02 \mathrm{~mL}$ test sample, and $0.02 \mathrm{~mL}$ AChE $(0.22 \mathrm{U} / \mathrm{mL})$ or $\mathrm{BChE}(0.1 \mathrm{U} / \mathrm{mL})$ solution were combined and incubated at $25^{\circ} \mathrm{C}$ for $15 \mathrm{~min}$ before adding $10 \mu \mathrm{L}$ of $0.5 \mathrm{mM}$ DTNB. The reaction was started with the addition of $10 \mu \mathrm{L}$ of $0.71 \mathrm{mM} \mathrm{AChl}$ or $0.2 \mathrm{mM} \mathrm{BChC}$ to the mixture. The substrate's hydrolysis was estimated at $412 \mathrm{~nm}$. By comparing the reactions of the samples with a blank, the percentage inhibition of AChE/ BChE was calculated.

\section{Antidiabetic activity}

\section{Inhibition of $\alpha$-glucosidase}

Inhibitory activity of the extract against $\alpha$-glucosidase was measured using the method reported by Abirami et al. ${ }^{18}$ Test sample $(50 \mu \mathrm{L})$ was combined with $0.1 \mathrm{~mL}$ of $0.1 \mathrm{M}$ phosphate buffer ( $\mathrm{pH}$ 6.8) and $0.1 \mathrm{~mL}$ of $1 \mathrm{U} / \mathrm{mL} \alpha$-glucosidase solution and incubated for $5 \mathrm{~min}$ at $25^{\circ} \mathrm{C}$. After pre-incubation, $0.1 \mathrm{~mL}$ of $5 \mathrm{mM} p$-nitrophenyl- $\alpha$ - $D$-glucopyranoside solution was applied to the reaction mixture, which was then incubated for $10 \mathrm{~min}$ at $25^{\circ} \mathrm{C}$. The absorbance at $405 \mathrm{~nm}$ was then measured and percent inhibition of $\alpha$-glucosidase was estimated.

\section{Inhibition of $\alpha$-amylase}

Inhibitory activity of the extract against $\alpha$-amylase was investigated using the method reported by Ademiluyi and Oboh. ${ }^{19}$ After boiling $0.5 \mathrm{~g}$ potato starch in $0.1 \mathrm{~L}$ phosphate buffer $(\mathrm{pH}$ 6.8) for $5 \mathrm{~min}$, the substrate was cooled to $25^{\circ} \mathrm{C}$. In a 96 well plate, $20 \mu \mathrm{L}$ of samples in different concentrations, $50 \mu \mathrm{L}$ of 0.1 $\mathrm{M}$ phosphate buffer $(\mathrm{pH}$ 6.8) and $10 \mu \mathrm{L}$ of $2 \mathrm{U} / \mathrm{mL} \alpha$-amylase solution were applied, and the mixture was incubated at $37^{\circ} \mathrm{C}$ for $15 \mathrm{~min}$. Following the preincubation, $20 \mu \mathrm{L}$ of starch solution was added. Then, $100 \mu \mathrm{L}$ of 3,5-dinitrosalicylic acid was added to the mixture as a coloring reagent and left in hot water for 10 min. Then, the absorbance was read using a microplate reader (Epoch, USA) at $540 \mathrm{~nm}$, and acarbose was used as a positive control.

\section{Statistical analysis}

The results are presented as mean \pm standard deviation (SD) of three parallel measurements. The analysis of variance was carried out with Graphpad prism software 7.0 (USA). Significant differences between means were determined using the student's $t$-test with $p<0.05$ considered significant.

\section{RESULTS AND DISCUSSION}

As part of our study on the biological activity of medicinal plants growing in Sivas province (Türkiye), in vitro antioxidant, anticholinesterase, and antidiabetic potential of an endemic species, i.e. T. argyrophyllum var. argyrophyllum was investigated. This research is the first to report on different biological activity investigations of $T$. argyrophyllum var. argyrophyllum except for its essential oil.
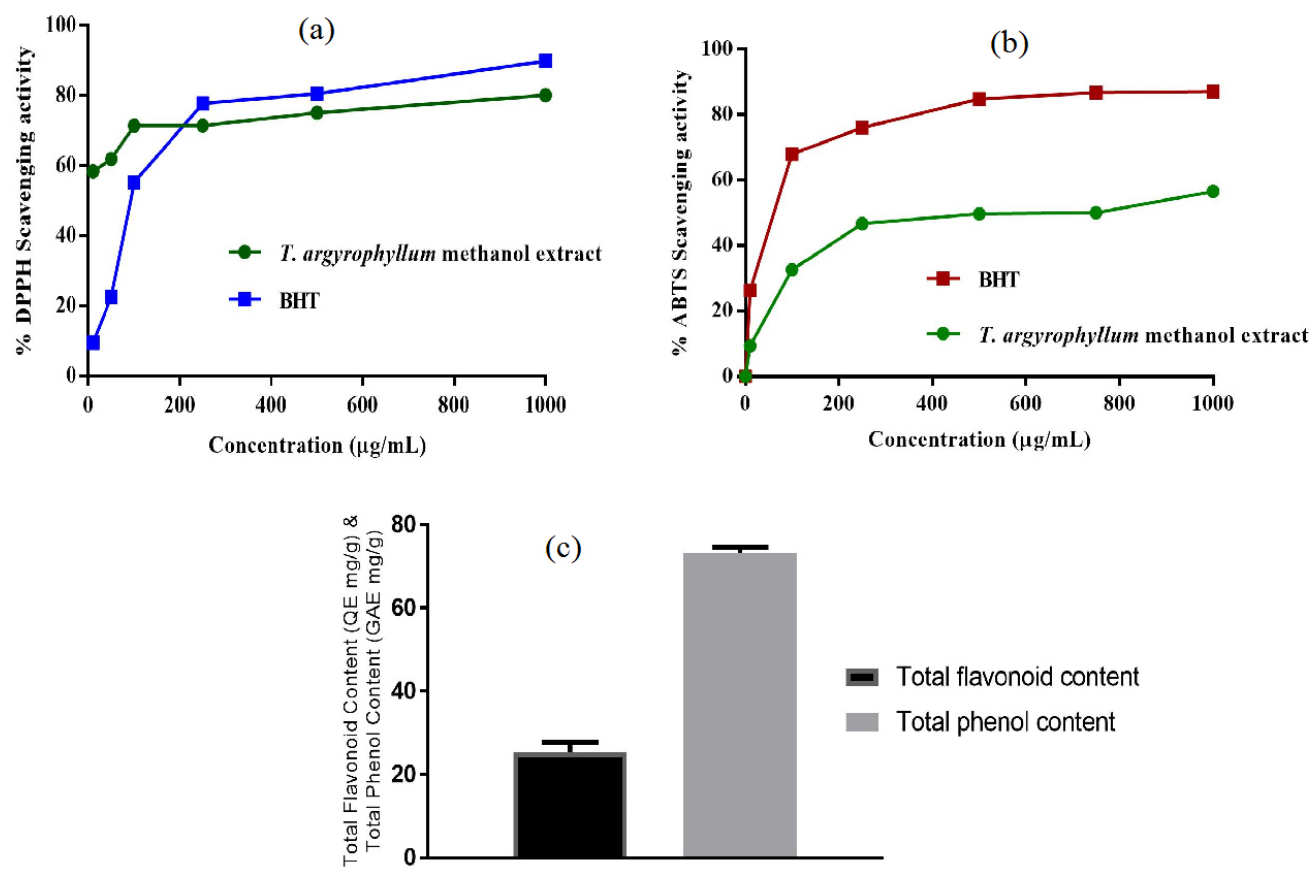

Total flavonoid content

Total phenol content

Figure 1. Total antioxidant activity results of Tanacetum argyrophyllum var. argyrophyllum aqueous methanol extract by DPPH, ABTS, TPC, and TFC methods DPPH: 2,2'-Diphenyl-1-picryl-hydrazyl, ABTS: 2,2-Azinobis (3-ethyl benzothiazoline-6-sulfonic acid) diammonium salt, TPC: Total phenolic content, TFC: Total flavonoid content 


\section{In vitro antioxidant activity}

Antioxidant activity of the aqueous methanol extract prepared from the aerial part of T. argyrophyllum var. argyrophyllum was evaluated using different in vitro methods. Total flavonoid and phenolic contents, as well as DPPH free radical and ABTS cation radical decolorization methods were used to assess the antioxidant activity. The results are given in Figure 1. Considering the antiradical activity, T. argyrophyllum var. argyrophyllum aqueous methanol extract exerted a remarkable DPPH scavenging effect, even stronger than that of standard (BHT) from 250 to $1000 \mu \mathrm{g} / \mathrm{mL}$ concentration. As for ABTS radical-scavenging effect, the aqueous methanol extract of $T$. argyrophyllum var. argyrophyllum demonstrated concentrationdependent activity; but showed lower radical scavenging activity than the reference (BHT).

Calibration equations were calculated as $Y=0.0066 x+0.1146$ $\left(R^{2}=0.9981\right)$ for TPC generated from gallic acid and $Y=0.0023 x$ + $0.1247\left(R^{2}=0.9971\right)$ for TFCs prepared from quercetin. Results of total phenol and flavonoid contents in the extract are shown in Figure 1. The aqueous methanol extract obtained from the aerial part of T. argyrophyllum var. argyrophyllum was found to contain total phenol amount $(71.67 \mathrm{mg} / \mathrm{GAE} \mathrm{g})$ as GAE and TFC

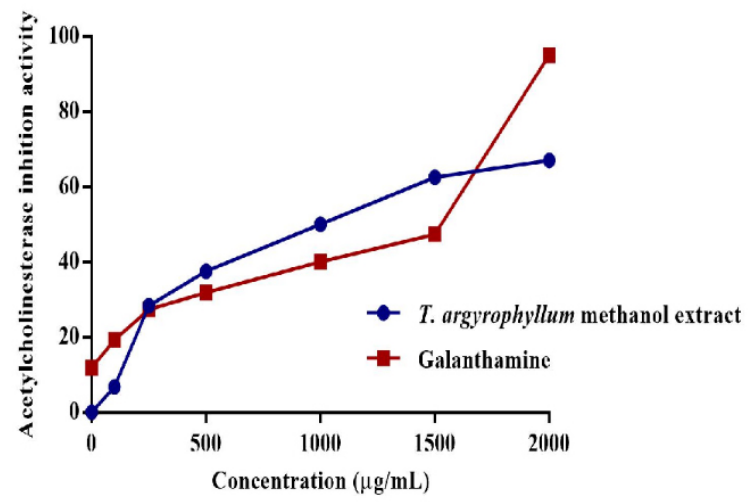

(25.225 mg/QE g) as QE on the dry weight basis of the extract. Wu et al..$^{20}$ identified phenolic compounds of $T$. parthenium and 3,5-, 4,5- and 3,4-di-O-caffeoylquinic acids were characterized as major compounds causing potent antioxidant activity of the plant. In another study, methanol extracts of three $T$. densum subspecies were screened for their antioxidant activities and a positive correlation was found between their TPC and antioxidant activity. ${ }^{21}$ Herein, flavonoid and phenolic compounds, which may be found in the methanol extract are supposed to be responsible for the antioxidant activity of $T$. argyrophyllum var. argyrophyllum.

\section{Anticholinesterase inhibition assay}

AChE and BChE inhibitory activities of T. argyrophyllum var. argyrophyllum aqueous methanol extract was determined by Ellman's spectrophotometric method. The extract was tested at different concentrations (10, 100, 250, 500, 1000, and $2000 \mu \mathrm{g} /$ $\mathrm{mL}$ ), the concentration-enzyme inhibition graph was generated, and compared with the standard (galantamine) (Figure 2). A lower $I C_{50}$ value indicates higher enzyme inhibition activity. IC $C_{50}$ values of the extract were obtained $266.79 \mu \mathrm{g} / \mathrm{mL}$ for AChE, $176.91 \mu \mathrm{g} / \mathrm{mL}$ for BChE. As can be seen from the antioxidant activity results, enzyme inhibition activity seems to be in

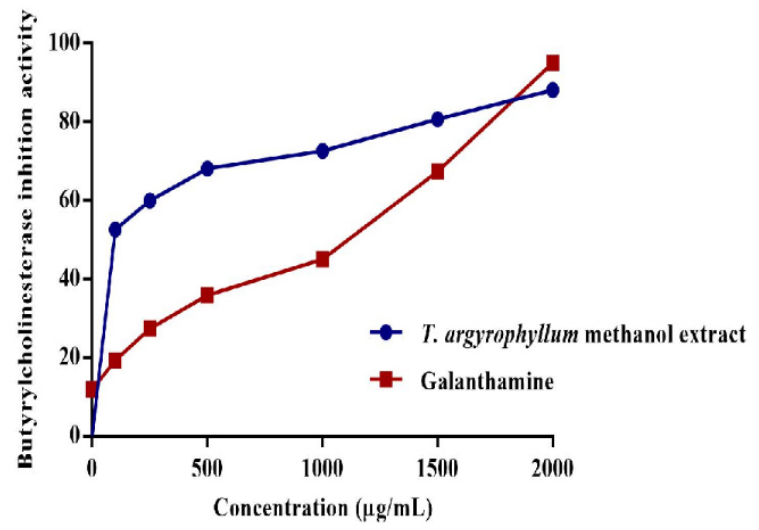

Figure 2. AChE and BChE inhibitory results of Tanacetum argyrophyllum var. argyrophyllum aqueous methanol extract with reference compound (galantamine)
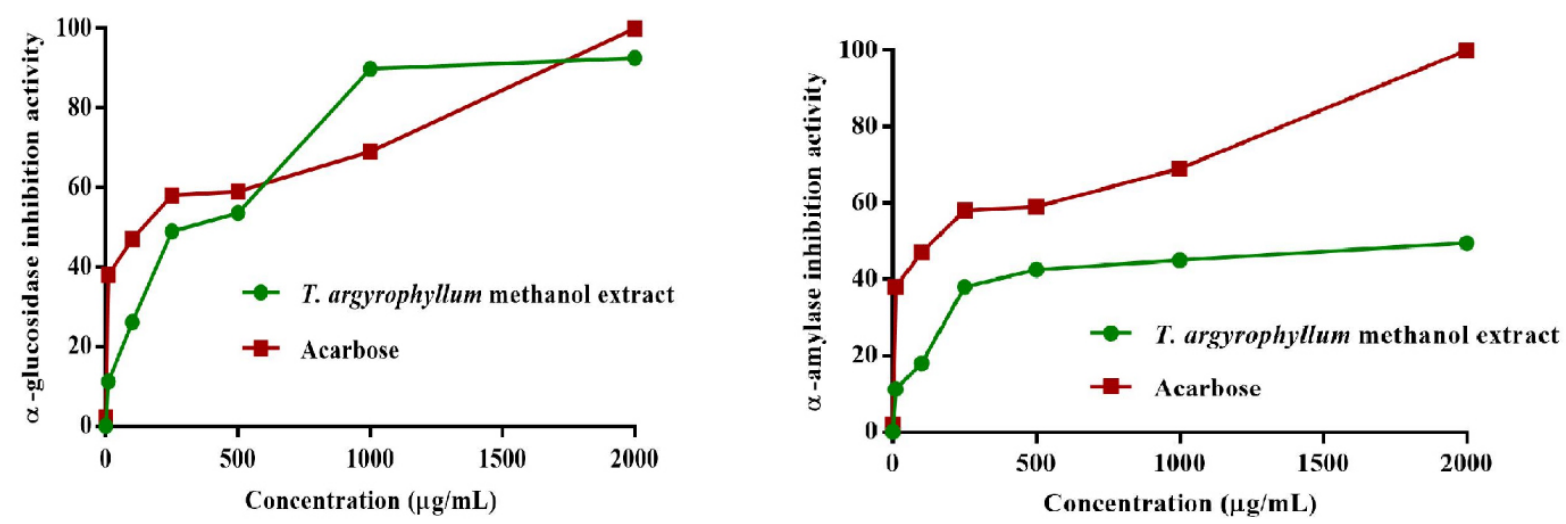

Figure 3. $\alpha$-Glucosidase and $\alpha$-amylase inhibitory results of Tanacetum argyrophyllum var. argyrophyllum aqueous methanol extract with reference compound (acarbose) 
accordance with total phenols and flavonoids contained. Wszelaki et al. ${ }^{22}$ observed that the methanolic and hexane extracts of T. parthenium Sch. Bip. ranged from $32.4 \%$ to $40.9 \%$ against AChE and BChE at a concentration of $400 \mu \mathrm{g} / \mathrm{mL}$. Orhan et al. ${ }^{23}$ investigated different Tanacetum taxa for their cholinesterase inhibitory activity and found that the leaf of T. argenteum (Lam.) Willd. subsp. flabellifolium (Boiss. \& Heldr.) Grierson had the highest inhibition of $96.68 \%$ at $100 \mu \mathrm{g} / \mathrm{mL}$ concentration against AChE, while T. argyrophyllum var. argyrophyllum showed the best inhibition of $63.81 \%$ against BChE. However, parthenolide, the main constituent of Tanacetum taxa has demonstrated lower inhibition activity against both enzymes. It can be concluded that the major compound parthenolide found in most Tanacetum taxa may not be active principle for their anticholinesterase activity or it can exert its activity by synergistic effect with other secondary metabolites. AChE inhibitory activity was tested on the essential oil of $T$. densum (Labill.) Heywood ssp. sivasicum Hub. - Mor. \& Grierson and T. mucroniferum Hub. Mor. \& Grierson. Pure oil showed 100\% inhibition, however, dilutions demonstrated lower inhibition. ${ }^{24}$ In another study on $T$. vulgare L. root, polyacetylenes were identified as the active zone for its antibacterial, antioxidant, and AChE inhibitory effects by HPTLC combined with in situ effect-directed analysis and spectrometric techniques. ${ }^{25}$

\section{Antidiabetic activity assays}

Inhibition of $\alpha$-amylase contributes to improving the symptoms of type-2 diabetes by delaying or cutting glucose absorption because of slowing starch digestion. While the primary goal of $\alpha$-amylase inhibition is to reduce the rate, at which maltose and glucose are produced from starch, this enzyme can slow down the function of $\alpha$-glucosidase by eliminating the substrate. ${ }^{26} \mathrm{~T}$. argyrophyllum var. argyrophyllum aqueous methanol extract concentration-dependently inhibited both $\alpha$-glucosidase and $\alpha$-amylase activity in vitro $\left(\mathrm{IC}_{50}\right.$ of 234.77 $\pm 1.76 \mu \mathrm{g} / \mathrm{mL}$ and $806.68 \pm 2.36 \mu \mathrm{g} / \mathrm{mL}$, respectively) compared with the positive control (acarbose) (Figure 3). A previous study on antidiabetic and enzyme inhibition properties of $T$. praeteritum (Horw.) Heywood essential oil revealed that the oil has a noteworthy inhibitory activity with $\mathrm{IC}_{50}$ of $0.89 \pm 0.13$ $\mathrm{mg} / \mathrm{mL}$ against porcine pancreatic $\alpha$-amylase. ${ }^{27}$ In another study, T. poteriifolium ethyl acetate extract exhibited inhibition in $\alpha$-glucosidase ( $23.67 \mathrm{mmol}$ acarbose equivalent/g extract) ${ }^{28}$ T. nubigenum, a Himalayan medicinal plant from India, showed potent stimulation of glucose uptake with $+61.2 \%$ in $\mathrm{C}_{2} \mathrm{Cl}_{2}$ myotubes. Also, ethanol extract of $T$. nubigenum decreased blood glucose level significantly in STZ induced SpragueDawley rats (15.5\%). ${ }^{29}$

\section{CONCLUSION}

According to the literature review, this study is the first investigation of T. argyrophyllum var. argyrophyllum in terms of antioxidant and enzyme inhibitory activities. This study showed that the aqueous methanol extract possessed polar compounds, which are rich in phenolic and flavonoid compounds, have strong antiradical, AChE, BChE, and AGl activity, while it demonstrated moderate $\alpha$-amylase inhibitory activity. This work will provide important scientific data for further phytochemical and biological activity-guided studies on the polar extract of $T$. argyrophyllum var. argyrophyllum to identify active principles that are attributed to the strong activity. However, to identify the active phytochemicals responsible for the antioxidant and enzyme inhibition activity, bioactivity-guided chromatographic fractionation and isolation must be performed.

\section{ACKNOWLEDGMENTS}

The authors want to thank the Sivas Cumhuriyet University Faculty of Pharmacy and Advanced Technology Research Center for providing laboratory facilities. This study was partly funded by Sivas Cumhuriyet University Scientific Research Project (CUBAP no: ECZ26 and ECZ31).

\section{Ethics}

Ethics Committee Approval: Not required.

Informed Consent: Not applicable.

Peer-review: Externally peer-reviewed.

\section{Authorship Contributions}

Concept: N.E., Design: N.E., Data Collection or Processing: N.E., K.T.A., O.Ü., M.T., Analysis or Interpretation: N.E., K.T.A., O.Ü., M.T., Literature Search: N.E., K.T.A., Writing: N.E., K.T.A.

Conflict of Interest: No conflict of interest was declared by the authors.

Financial Disclosure: This study was partly funded by the Sivas Cumhuriyet University Scientific Research Projects (CUBAP no: ECZ26 and ECZ31).

\section{REFERENCES}

1. Davis, HP. Flora of Turkey and The East Aegean Islands. Edingburgh; Edinburgh University Press; 1982.

2. Güner A. Türkiye Bitkileri Listesi, Damarlı Bitkiler (1st ed). İstanbul; Nezahat Gökyiğit Botanik Bahçesi Yayınları; 2012.

3. Akpulat HA, Tepe B, Sokmen A, Daferera D, Polissiou, M. Composition of the essential oils of Tanacetum argyrophyllum (K. Koch) Tzvelev. var. argyrophyllum and Tanacetum parthenium (L.) Schultz Bip. (Asteraceae) from Turkey. Biochem Syst Ecol. 2005;33:511-516.

4. Gören N, Arda N, Çaliskan Z. Chemical characterization and biological activities of the genus Tanacetum (Compositae). Stud Nat Prod Chem. 2002;27:547-658.

5. Kumar V, Tyagi, D. Chemical composition and biological activities of essential oils of genus Tanacetum - a review. J Pharmacogn Phytochem. 2013;2:159-163.

6. Abad MJ, Bermejo P, Villar A. An approach to the genus Tanacetum L. (Compositae): phytochemical and pharmacological review. Phyther Res. 1995;9:79-92.

7. Polatoglu K, Demirci F, Demirci B, Gören N, Can Baser KH. Antimicrobial activity and essential oil composition of a new T. argyrophyllum (K. Koch) Tzvelev var. argyrophyllum chemotype. J Oleo Sci. 2010;59:307-313.

8. Öztürk M, Duru ME, Kivrak S, Mercan-Doğan N, Türkoglu A, Özler MA. In vitro antioxidant, anticholinesterase and antimicrobial activity studies on 
three Agaricus species with fatty acid compositions and iron contents: a comparative study on the three most edible mushrooms. Food Chem Toxicol. 2011;49:1353-1360.

9. Aktumsek A, Zengin G, Guler GO, Cakmak YS, Duran A. Antioxidant potentials and anticholinesterase activities of methanolic and aqueous extracts of three endemic Centaurea L. species. Food Chem Toxicol. 2013;55:290-296.

10. Orhan IE, Sezer Senol F, Ercetin T, Kahraman A, Celep F, Akaydin G, Sener B, Dogan M. Assessment of anticholinesterase and antioxidant properties of selected sage (Salvia) species with their total phenol and flavonoid contents. Ind Crops Prod. 2013;41:21-30.

11. Poovitha S, Parani M. In vitro and in vivo $\alpha$-amylase and $\alpha$-glucosidase inhibiting activities of the protein extracts from two varieties of bitter gourd (Momordica charantia L.). BMC Compl Alternative Med. 2016;16(Suppl 1):185.

12. Liu S, Yu Z, Zhu H, Zhang W, Chen Y. In vitro $\alpha$-glucosidase inhibitory activity of isolated fractions from water extract of qingzhuan dark tea. BMC Compl Alternative Med. 2016;16:1-8.

13. Ainsworth EA, Gillespie KM. Estimation of total phenolic content and other oxidation substrates in plant tissues using Folin-Ciocalteu reagent. Nat Protoc. 2007;2:875-877.

14. Yang H, Dong Y, Du H, Shi H, Peng Y, Li X. Antioxidant compounds from propolis collected in Anhui, China. Molecules. 2011;16:3444-3455.

15. Wang H, Gao XD, Zhou GC, Cai L, Yao WB. In vitro and in vivo antioxidant activity of aqueous extract from Choerospondias axillaris. Food Chem. 2008;106:888-895.

16. Re R, Pellegrini N, Proteggente A, Pannala A, Yang M, Rice-Evans C. Antioxidant activity applying an improved ABTS radical cation decolorization assay. Free Radic Biol Med. 1999;26:1231-1237.

17. Ellman GL, Courtney KD, Andres V Jr, Feather-Stone RM. A new and rapid colorimetric determination of acetylcholinesterase activity. Biochem Pharmacol. 1961;7:88-95.

18. Abirami A, Nagarani G, Siddhuraju P. In vitro antioxidant, anti-diabetic, cholinesterase and tyrosinase inhibitory potential of fresh juice from Citrus hystrix and C. maxima fruits. Food Sci Hum Wellness. 2014;3:1625.

19. Ademiluyi AO, Oboh G. Soybean phenolic-rich extracts inhibit keyenzymes linked to type 2 diabetes ( $\alpha$-amylase and $\alpha$-glucosidase) and hypertension (angiotensin I converting enzyme) in vitro. Exp Toxicol Pathol. 2013;65:305-309.

20. Wu C, Chen F, Wang X, Wu Y, Dong M, He G, Galyean RD, He L, Huang $G$. Identification of antioxidant phenolic compounds in feverfew (Tanacetum parthenium) by HPLC-ESI-MS/MS and NMR. Phytochem Anal. 2007;18:401-410.

21. Tepe B, Sokmen A. Screening of the antioxidative properties and total phenolic contents of three endemic Tanacetum subspecies from Turkish flora. Bioresour Technol. 2007;98:3076-3079.

22. Wszelaki N, Kuciun A, Kiss AK. Screening of traditional European herbal medicines for acetylcholinesterase and butyrylcholinesterase inhibitory activity. Acta Pharm. 2010;60:119-128.

23. Orhan IE, Tosun F, Gülpınar AR, Kartal M, Duran A, Mihoglugil F, Akalgan D. LC-MS quantification of parthenolide and cholinesterase inhibitory potential of selected Tanacetum L. (Emend. Briq.) taxa. Phytochem Lett. 2015;11:347-352.

24. Polatoğlu K, Servi H, Yücel Yücel Y, Nalbantsoy A. Cytotoxicity acetylcholinesterase inhibitory and PRAP activities of the essential oils of selected Tanacetum L. species. Nat Volatiles \& Essent Oils. 2015;2:1116.

25. Móricz ÁM, Ott PG, Morlock GE. Discovered acetylcholinesterase inhibition and antibacterial activity of polyacetylenes in tansy root extract via effect-directed chromatographic fingerprints. J Chromatogr A. 2018;1543:73-80.

26. Jemaa HB, Jemia AB, Khlifi S, Ahmed HB, Slama FB, Benzarti A, Elati J, Aouidet A. Antioxidant activity and a-amylase inhibitory potential of Rosa canina L. Afr J Tradit Complement Altern Med. 2017;14:1-8.

27. Özek G. Chemical diversity and biological potential of Tanacetum praeteritum subsp. praeteritum essential oils. JOTCSA. 2018;5:493-510.

28. Zengin G, Cvetanović A, Gašić U, Stupar A, Bulut G, Şenkardes I, Dogan A, Sinan KI, Uysal S, Aumeeruddy-Elalfi Z, Aktumsek A, Mahomoodally MF. Modern and traditional extraction techniques affect chemical composition and bioactivity of Tanacetum parthenium (L.) Sch.Bip. Ind Crops Prod. 2020;146:112202.

29. Khan MF, Rawat AK, Khatoon S, Hussain MK, Mishra A, Negi DS. In vitro and in vivo antidiabetic effect of extracts of Melia azedarach, Zanthoxylum alatum, and Tanacetum nubigenum. Integr Med Res. 2018;7:176-183. 